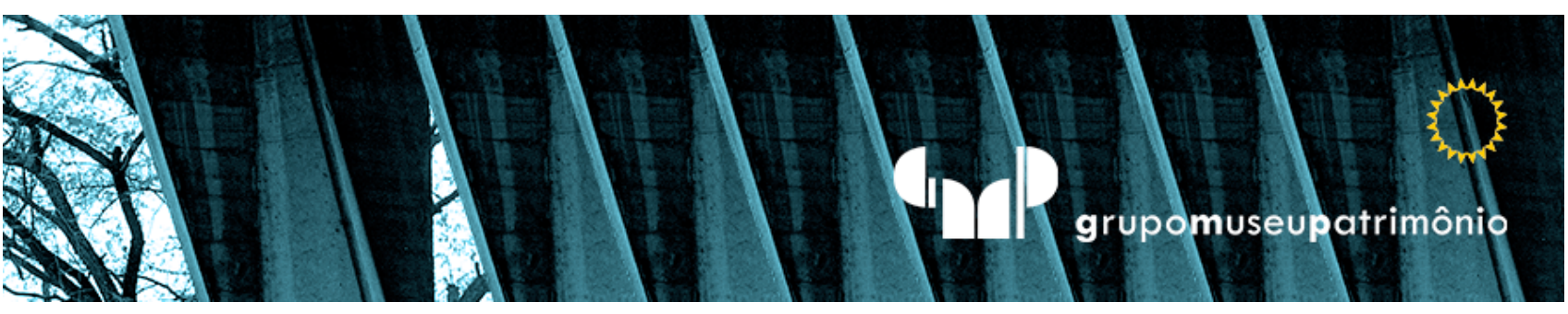

\title{
Camadas de tempo e espaço no painel de azulejaria Kilomètre 47, de Maria Helena Vieira da Silva
}

\author{
Capas de tiempo y espacio en el \\ panel de azulejos Kilomètre 47, de \\ Maria Helena Vieira da Silva
}

Layers of time and space on the Kilomètre 47 tile panel, by Maria Helena Vieira da Silva

Helio Herbst

Universidade Federal Rural do Rio de Janeiro, Seropédica, Brasil helioherbst@gmail.com 


\title{
Resumo
}

Nos anos de exílio, em 1943, a artista luso-francesa Maria Helena Vieira da Silva elaborou um painel de azulejaria para o refeitório de um novo campus universitário, situado no quilômetro 47 da rodovia Rio-São Paulo, no antigo distrito de Seropédica. $O$ presente artigo pretende examinar, sob o amparo do conceito benjaminiano de experiência (Erfahrung), as narrativas evocadas pelas temporalidades não-lineares e pelas espacialidades inscritas nesta obra. Sob tal enfoque, o painel Kilomètre 47 pode ser visto como uma homenagem ao trabalho no campo, uma ode à simplicidade, um tributo à mulher, uma deferência às tradições lusitanas. Mas também pode ser interpretado como o reencontro da artista consigo mesma, ou ainda, como uma introjeção pessoal que vislumbra uma dimensão coletiva, a um só tempo poética e potencialmente transformadora.

Palavras-Chave: Azulejo. Arte. Narrativa. Tradição. Identidade.

\section{Resumen}

En los años del exilio, en 1943, la artista franco-portuguesa Maria Helena Vieira da Silva preparó un panel de azulejos para el restaurante de un nuevo campus universitario, ubicado en el kilómetro 47 de la carretera Río-São Paulo, en el antiguo distrito de Seropédica. Este artículo pretende examinar, apoyándose en el concepto de experiencia de Benjamin (Erfahrung), las narrativas evocadas por las temporalidades no lineales y las espacialidades inscritas en esta obra. Bajo tal enfoque, el panel Kilomètre 47 puede verse como un homenaje al trabajo campesino, una oda a la sencillez, un homenaje a la mujer, una deferencia a las tradiciones lusitanas. Pero también se puede interpretar como el reencuentro de la artista consigo misma, o como una introyección personal que vislumbra una dimensión colectiva, al mismo tiempo poética y potencialmente transformadora.

Palabras-Clave: Azulejo. Art. Narrativa. Tradición. Identidad.

\begin{abstract}
In the years of exile, in 1943, the Portuguese French artist Maria Helena Vieira da Silva prepared a tile panel for the cafeteria of a new university campus, located at kilometre 47 of the Rio-São Paulo highway, in the old district of Seropédica. This article intends to examine, under the support of the Benjamin concept of experience (Erfahrung), the narratives evoked by nonlinear temporalities and the specialities inscribed on the Kilomètre 47 tile panel. Under such approach, the work can be seen as a tribute to work in the field, as an ode to simplicity, as a tribute to women, as a deference to Lusitanian traditions. But it can also be interpreted as the artist's reunion with herself, or as an introjection that envisions a collective dimension, at the same time poetic and potentially transformative.
\end{abstract}

Keywords: Tile. Art Narrative. Tradition. Identity. 


\section{INTRODUÇÃO}

m 1943, Maria Helena Vieira da Silva concebeu e executou um painel de azulejaria, denominado Kilomètre $47^{1}$, para o refeitório estudantil do Centro Nacional de Estudos e Pesquisas Agronômicas (CNEPA). A instituição, criada durante - Estado Novo varguista, constitui o núcleo embrionário da Universidade Rural, fundada em 30 de dezembro de 1943 pelo Decreto-Lei $6.155^{2}$.

A encomenda, feita por indicação da amiga Cecília Meireles, esposa de Heitor Grillo, diretor geral do CNEPA, constitui uma obra singular na trajetória de Vieira da Silva.

\footnotetext{
${ }^{1}$ O presente artigo demarca uma etapa da investigação de pós-doutorado "Na espessura do plano: as narrativas plasmadas pelos painéis de azulejaria concebidos por Vieira da Silva para o refeitório da Universidade Rural", em desenvolvimento no Grupo Museu Patrimônio, na FAU/USP, sob supervisão da professora Maria Cecília França Lourenço, com etapa de investigação realizada em Lisboa, como pesquisador visitante no DINÂMIA'CET ISCTE-IUL, sob orientação da professora Paula André.

${ }^{2}$ A origem da universidade remonta a 1910, com a abertura da Escola Superior de Agricultura e Medicina Veterinária (ESAMV), por meio do Decreto-Lei 8.319, publicado em 20 de outubro de 1910. 0 labríntico processo de criação da Universidade Rural pode ser consultado em: ARAUJO, Regina Célia Lopes. $A$ universidade no contexto urbano: as representações presentes na relação socioespacial entre a Universidade Federal Rural do Rio de Janeiro e a cidade de Seropédica. 2011. Tese de Doutorado. Instituto de Pesquisa e Planejamento Urbano e Regional, Universidade Federal do Rio de Janeiro, Rio de Janeiro, 2011.
} 
Tal importância se expressa pela possibilidade de contato com procedimentos técnicos até então inexplorados, contribuindo para recapitular as tradições da sua terra natal ${ }^{3}$. O painel possui oito partes distribuídas em uma parede de aproximadamente $16 \times$ 4,40 metros, organizadas a partir de um quadro central que apresenta uma laranjeira carregada de frutos e, sob sua copa, duas camponesas simetricamente dispostas em relação ao tronco da árvore.

Levando-se em conta a materialidade e a estrutura compositiva do objeto de estudo, o presente artigo pretende examinar, sob o amparo do conceito benjaminiano de experiência (Erfahrung), as narrativas estimuladas pelo painel, de modo a evocar temporalidades não-lineares e espacialidades fragmentadas. Analisada sob esse prisma, a encomenda torna-se aberta a múltiplas interpretações, nas quais o saber provém do acúmulo de experiências pessoais e coletivas.

\section{VIEIRA DA SILVA NO BRASIL, UMA CONTINGÊNCIA NECESSÁRIA}

Maria Helena Vieira da Silva nasceu em 1908 na cidade de Lisboa e desde cedo manifestou interesse pelas artes visuais. Com apoio da família, mudou-se para Paris em 1928. Na capital francesa frequentou a Académie de La Grande Chaumière, em que conheceu Arpad Szenes, húngaro de ascendência judaica, com quem se casou em 1930, perdendo a nacionalidade portuguesa, por imposição do Código Civil então vigente. (CESARINY, 2008, p. 51-53)

Em 1939, temendo uma iminente invasão das tropas do nazi-fascismo alemão, partiram para Lisboa, com a expectativa de Maria Helena recuperar a cidadania perdida e Arpad naturalizar-se português. Diante da dupla negativa e da persistente sensação de desamparo, o casal decidiu se refugiar no Rio de Janeiro, sendo a escolha contingencial, decorrente da existência de alguns contatos na cidade e de algumas facilidades para a obtenção de vistos na embaixada brasileira em Lisboa.

\footnotetext{
${ }^{3}$ Conforme sentencia Vieira da Silva. os azulejos, admirados desde a infância, estão sempre "prontos a reaparecer" em sua obra plástica, "em passo de dança, escapulindo-se e esvoaçando... velozes, num golpe de asa". (VIEIRA DA SILVA. In: WEELEN, Guy. O azulejo. Lisboa: Imprensa Nacional: Casa da Moeda, 1992 , n.p.)
} 
Em 1940, depois de uma estada de seis meses em Copacabana, mudaram-se para a pensão das russas, no Flamengo, por indicação do também residente Murilo Mendes. (LAMEGO, 2007, p. 60) Dali se transferiram para o Hotel Internacional, em Santa Teresa, naquela altura transformado em Pensão Internacional, opção econômica para exilados ou recém-chegados à cidade, a exemplo de António Botto, poeta português; Carlos Scliar, pintor gaúcho; Jacques Van de Beuque, arquiteto belga; e Rubem Navarra, crítico de arte paraibano (MORAIS, 1986).

O local rapidamente se tornou em ponto de encontro alternativo aos saraus realizados na casa de Aníbal Machado, em Ipanema, e aos debates dos cafés Amarelinho e Vermelhinho, na Cinelândia ${ }^{4}$. Circularam pela Pensão Internacional os pintores Athos Bulcão, Carlos Scliar, Djanira e Milton Dacosta e os poetas Cecília Meireles, Manuel Bandeira e Murilo Mendes (PAULA, 1994-1995, p. 273).

Sem recorrer aos préstimos de pintores de maior evidência naqueles anos, notadamente Cândido Portinari, Arpad e Maria Helena conquistaram reconhecimento no ambiente artístico brasileiro, ainda refratário aos preceitos da pintura não-figurativa. Juntos participaram do 48으 Salão Nacional de Belas Artes (1942), de uma mostra de ilustrações da publicação Contos do Mundo: os russos antigos e modernos (1944), realizada na sede nacional do Instituto de Arquitetos do Brasil (IAB) e de uma exposição no Palácio das Artes (1946), em Belo Horizonte. Arpad realizou uma individual (1946) na sede nacional do IAB; Vieira da Silva expôs individualmente no Museu Nacional de Belas Artes (1942) e na Galeria Askanazy (1944), no centro do Rio de Janeiro. (MORAIS, 1986)

A relação dos contatos e exposições não é fortuita, mas indicativa de um considerável esforço para se manter o ritmo de produção da temporada parisiense. Afastados da pátria de escolha nos altos de Santa Teresa, nas ruínas de um empreendimento hoteleiro outrora sofisticado, Arpad e Maria Helena encontraram motivos para resistir e seguir adiante, apesar das incertezas em relação ao futuro.

\footnotetext{
${ }^{4}$ De acordo com o depoimento da artista France Dupaty, "todo o mundo" frequentava o Bar Vermelhinho, "menos o Arpad e Maria Helena. Esta achava que as pessoas, no Brasil, não eram sérias". (DUPATY. In: MORAES, 1986, n.p.)
} 
Em paralelo à rotina do ateliê, Arpad montou um curso de pintura sem imaginar que chegaria a receber "mais de duzentos alunos" ${ }^{5}$. As despesas do casal eram parcialmente supridas com a realização de ilustrações, sendo particularmente relevantes os trabalhos realizados para publicações de Cecília Meireles e Murilo Mendes, ampliando o espectro dos debates em torno do raciocínio construtivo.

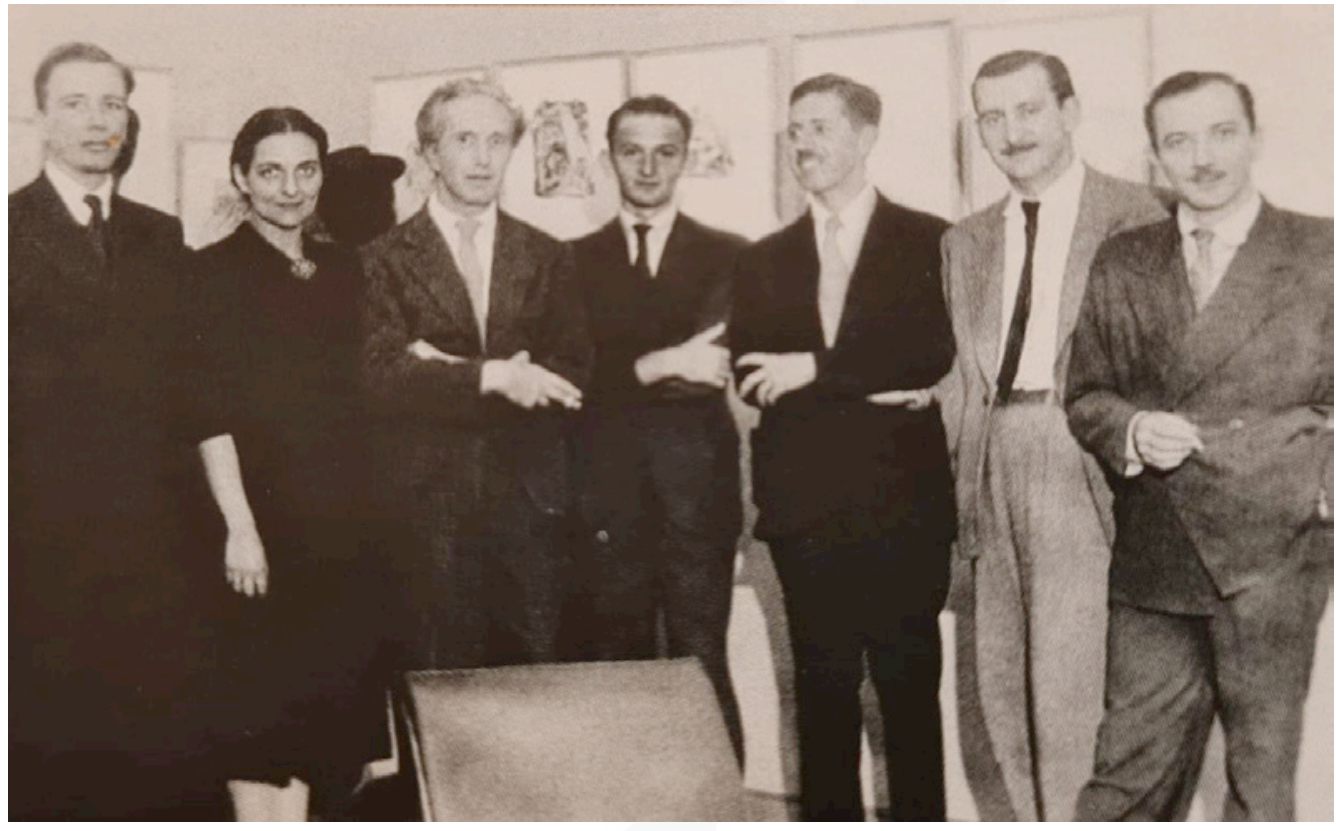

Figura 1. Eros Martim Gonçalves, Vieira da Silva, Arpad Szenes, Carlos Scliar, Alcides Rocha Miranda, Roberto Burle Marx e Augusto Rodrigues na inauguração de coletiva realizada na sede nacional do Instituto de Arquitetos do Brasil, 1944. Autoria desconhecida.

Fonte: revista Leitura, maio 1944.

Também por intermédio de Cecília Meireles, Arpad realizou uma série de retratos para compor a sala da reitoria, situada no Pavilhão das Academias, e Vieira da Silva executou o painel de azulejaria Kilomètre 47, instalado no refeitório estudantil do novo campus universitário. Apesar da ajuda, o casal encontrava dificuldades para driblar a escassez de recursos, esforçando-se para suportar o isolamento e a tensão dos anos de guerra em um país estrangeiro. Nas palavras da própria artista, o exílio no Brasil foi fascinante, mas profundamente doloroso:

\footnotetext{
${ }^{5}$ Almir Mavignier, Bela Kennedy, Frank Schaeffer e Genaro Vidal, entre muitos outros, frequentaram as aulas ministradas por Arpad Szenes no ateliê Silvestre, conforme indica Frederico Morais em Cronologia das Artes Plásticas no Rio de Janeiro. (MORAIS, 1995, p. 200)
} 
Ninguém comprava nada àquela época no Brasil. [...] Por um lado, penso que foi uma sorte que as pessoas ricas não nos procurassem para comprar quadros. Tivéssemos caído nas graças dos grã-finos e não teríamos tido aquela vida contemplativa. Mas, claro, era muito bonita porque acabou, porque foi angustiante para nós. Sentíamos tudo muito frágil. [...] Vivíamos assim como uma borboleta (VIEIRA DA SILVA. In: MORAIS, 1986, n.p.)

Em fevereiro de 1947, Maria Helena regressou a Paris. Quatro meses depois, Arpad seguiu o mesmo rumo. Nunca mais retornaram ao Brasil, mas as lembranças de um tempo de dificuldades, de perdas, mas também de conquistas, permaneceram latentes. A memória desconhece a ordem linear do tempo. E não prescreve.

\section{UM PASSEIO PELAS CAMADAS DO PAINEL KILOMÈTRE 47}

Em 1938, por determinação de Fernando Costa, ministro da Agricultura, e anuência do presidente Getúlio Vargas, foi iniciada a implantação do Centro Nacional de Estudos e Pesquisas Agronômicas (CNEPA) em uma gleba de 1.024 alqueires cuja existência remonta à expansão e transformação da sesmaria de Cristóvão Monteiro na Imperial Fazenda de Santa Cruz, configurando um latifúndio que se estendia de Mangaratiba a Vassouras ${ }^{6}$. A fração do terreno correspondente ao campus situava-se no distrito de Seropédica, naquela altura pertencente ao município de Itaguaí, no quilômetro 47 da antiga rodovia Rio-São Paulo, a cerca de setenta e cinco quilômetros do Rio de Janeiro, Capital Federal.

Em 1943, cinco anos depois do lançamento da pedra fundamental, Arpad e Maria Helena foram contratados para conceber trabalhos artísticos para a nascente universidade. De acordo com o parecer do conselheiro Gerardo Mello Mourão, incluído no relatório que sustenta o processo de tombamento, em nível estadual, das edificações do núcleo embrionário do campus, incluindo-se a obra de Vieira da Silva,

\footnotetext{
${ }^{6}$ A propriedade também pertenceu à Companhia de Jesus, em grande medida responsável pelo processo ocupação e expansão territorial. Para maiores informações, sugerimos a consulta de: PEREIRA, Júlio César Medeiros da Silva. Práticas de saúde, doenças e sociabilidade escrava na Imperial Fazenda de Santa Cruz, da segunda metade do século XIX. Histórica - Revista do Arquivo Público do Estado de São Paulo, São Paulo, n. 35, 2009.
} 
a ideia e os recursos necessários para a instalação do painel devem ser creditados ao senador e colecionador de azulejos Antônio de Barros Carvalho ${ }^{7}$.

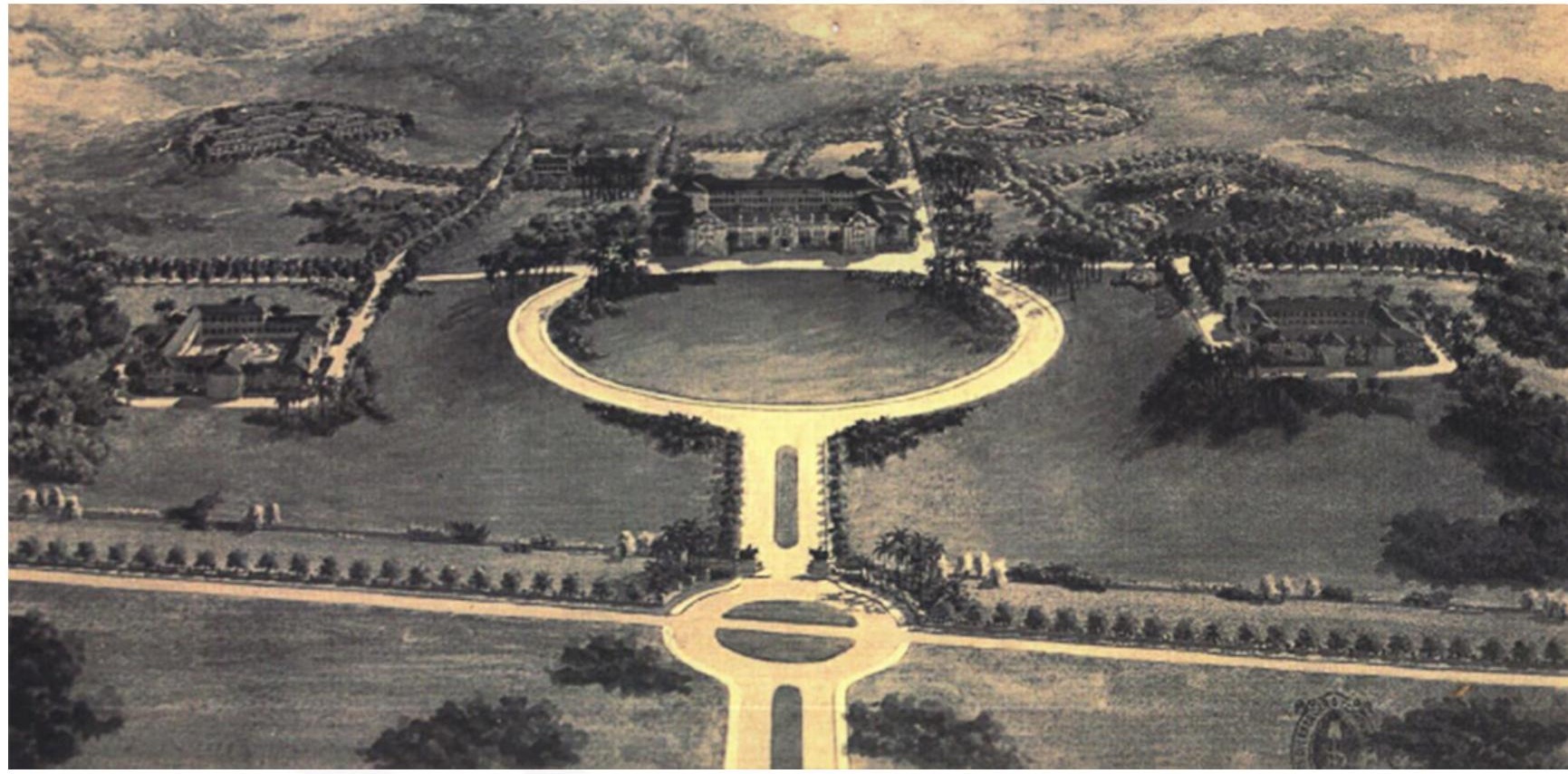

Figura 2. Concepção do projeto, s/d. Autoria desconhecida. Fonte: MONTEIRO et. al. 1998, n. p.

O core da universidade é conformado por três pavilhões dispostos simetricamente em torno de uma grande esplanada gramada que transforma o deslocamento pela via de ingresso no campus em um espetáculo de forte impacto visual. Cada um desses pavilhões possui portada de entrada centralizada, planta quadrada e circulação em torno de pátios internos assemelhados a claustros, circundados por galerias sobrepostas e arqueadas. As coberturas, em telhado aparente, são adornadas com pináculos e frontões com volutas.

O refeitório, local de instalação do painel Kilomètre 47 , situa-se cerca de quinhentos metros da reitoria, no prédio de acesso ao Setor de Alojamentos, cujo projeto

70 parecer de Mourão sobre o tombamento do núcleo embrionário do campus da Universidade Rural encontra-se anexado em: MONTEIRO M.C.; MATTOS, R.P. de; BIASE, T. de; FERRAZ, G.M. dos S. Inventário de bens imóveis - ficha sumária da Universidade Federal Rural do Rio de Janeiro - Km 47 da Rodovia BR-465, antiga estrada Rio/São Paulo. Proc.: E-18/001540/98. Rio de Janeiro: INEPAC, 1998. 
arquitetônico é assinado pelo engenheiro-arquiteto Eduardo da Veiga Soares. O edifício, também conhecido como o Prédio da Cooperativa dos Alunos da Universidade Rural (CAUR) ou o Prédio do Diretório Central do Estudantes (DCE), caracteriza-se pela composição não simétrica de volumes e por uma certa simplificação dos elementos ornamentais, se comparado com a sede administrativa.

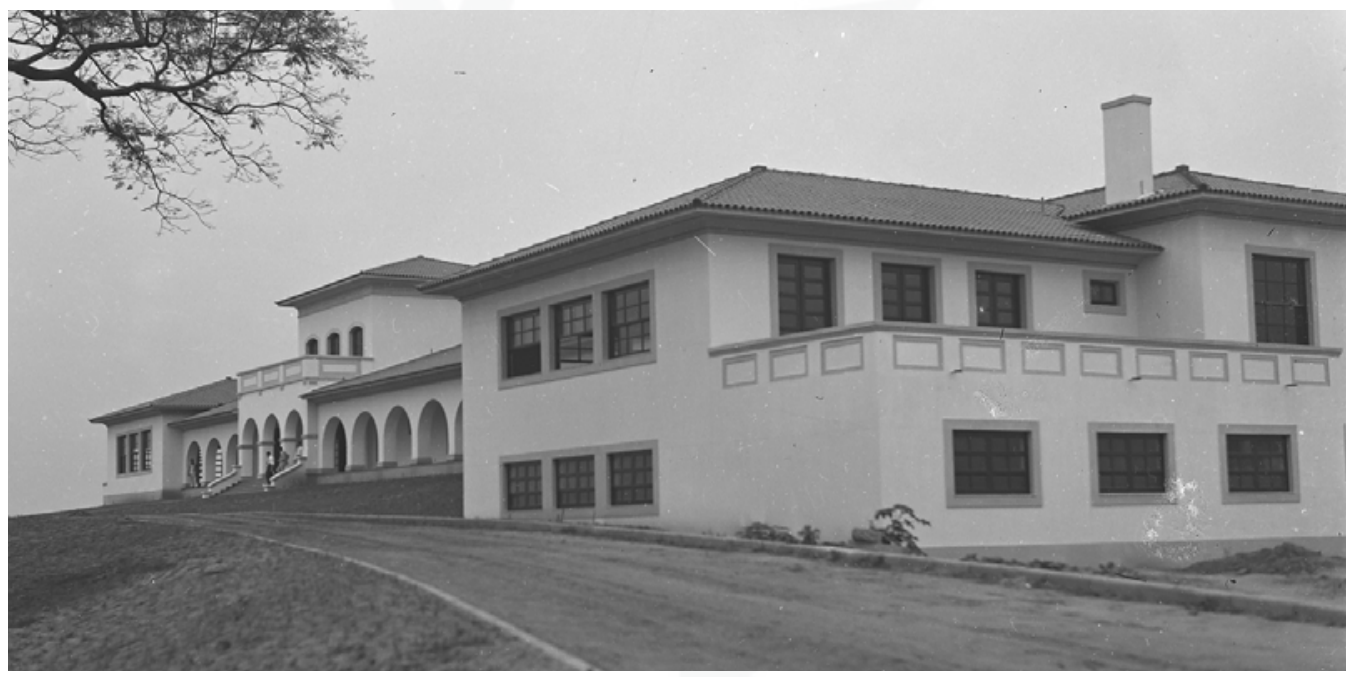

Figura 3: Prédio da CAUR, s/d. Autoria desconhecida. Fonte: portal Arquivo Nacional

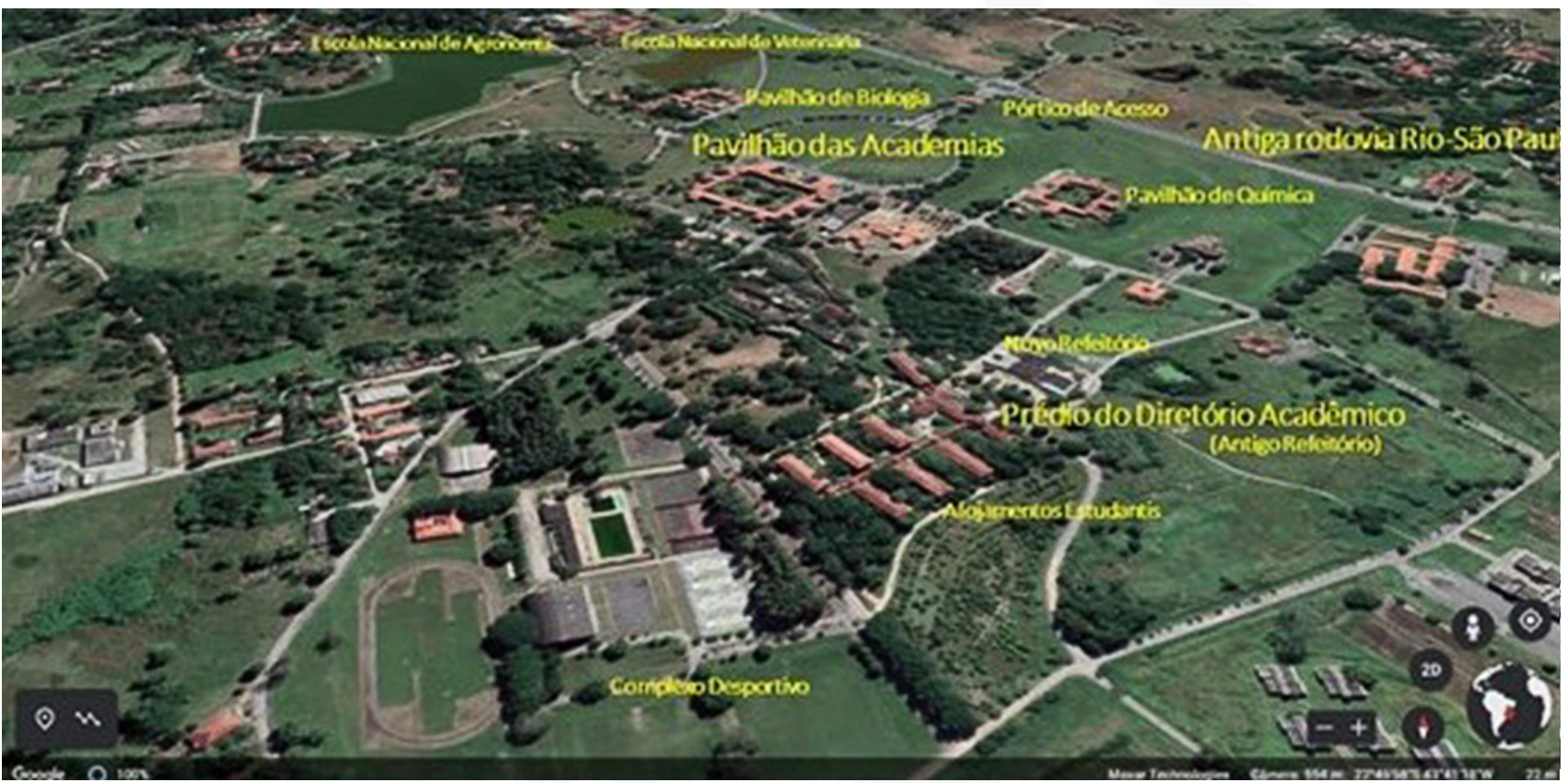

Figura 4: Vista aérea do campus, 2021 Fonte: Google Earth, modificada pelo autor 
O painel, instalado em uma das laterais do refeitório, subdivide-se em oito partes visualmente estruturadas pelo quadro central e por dois módulos simétricos de acentuada verticalidade, conectados na base por uma fiada de azulejos, que funciona como rodapé. Tal embasamento se prolonga para as outras paredes do salão e contorna todas as portas-balcão e janelas, de modo a criar uma expansão visual que envolve o ambiente, de modo a conferir uma completa integração da obra com o projeto arquitetônico.

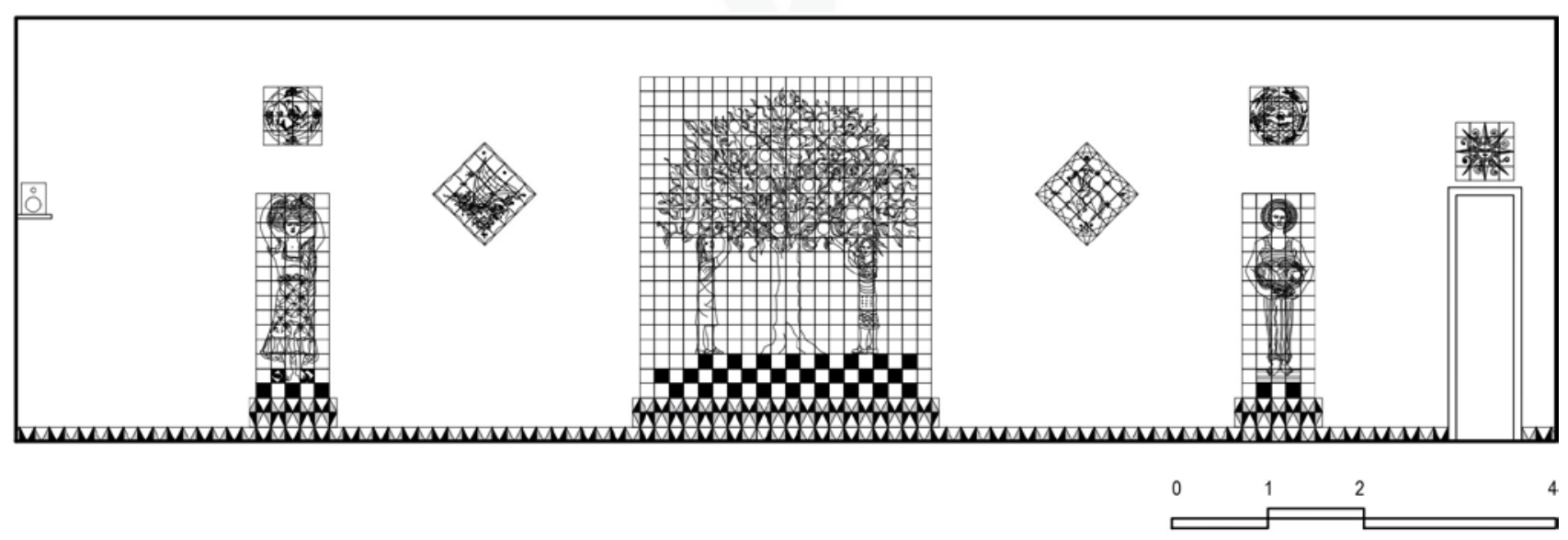

Figura 5. Elevação do painel, elaborada a partir de registros fotográficos. Fonte: desenho Renan Santana, bolsista PIBIC, 2021

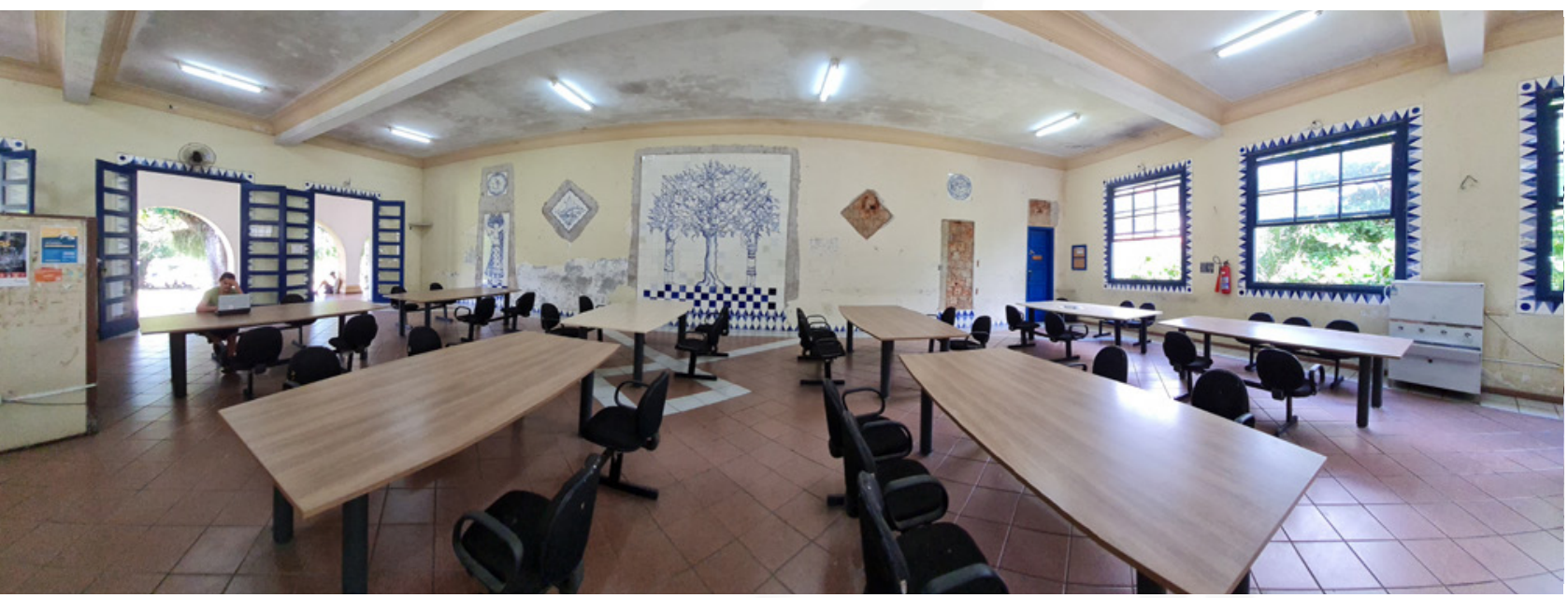

Figura 6: Panorama do conjunto em março de 2021. A imagem registra a atual etapa dos trabalhos de conservação do painel. Ressalte-se que, dos oito quadros que compõem o painel, cinco já foram restaurados e assentados e três aguardam recolocação Fonte: foto do autor, 2021 
Múltiplas estratégias poderiam ser usadas para descrever o painel. No presente artigo, optamos por analisar suas oito partes em ordem não sequencial, de tal modo a contemplar o todo a partir de sugestões lançadas pelos diferentes quadros, libertando o olhar para admirar cada peça isoladamente, ao mesmo tempo que em tal exercício se observa o conjunto por diferentes aproximações, sempre a partir de algum elemento presente ou evocado pela obra. Tentaremos esboçar uma análise articulada com um método de composição que recorre a recortes e saltos para articular imagens dialéticas, situadas no limiar entre o consciente e o inconsciente, suspensas em um tempo de reflexão, no qual o passado se anuncia em lampejos, formando constelações. Nas palavras de Benjamin,

Não é que o passado lança sua luz sobre o presente ou que o presente lança sua luz sobre o passado: mas a imagem é aquilo em que o ocorrido encontra o agora num lampejo, formando uma constelação. Em outras palavras: a imagem é a dialética na imobilidade. (BENJAMIN, 2006, p. 504)

Nesta deambulação de inspiração benjaminiana, podemos imaginar as reflexões de um estudante-flâneur que percorre a via monumental de acesso do campus recéminaugurado, no final dos anos 1940. Num primeiro momento ele se depara com a magnitude do Pavilhão das Academias e depois ingressa nas vias secundárias do campus. Imerso em atmosfera mais afeita com a sua própria escala, avista no topo de uma pequena colina o Prédio da CAUR, cuja horizontalidade integra-se mais facilmente com a paisagem circundante.

Para entrar no edifício, serve-se de uma escadaria que demarca o corpo central da composição e organiza duas linhas de percursos, perpendiculares entre si: a primeira conduz aos pavilhões de alojamento, distribuídos alternadamente ao longo de uma marquise que prolonga o eixo central do prédio em direção ao centro desportivo; os outros dois trajetos se inscrevem em uma circulação coberta que faceia a fachada principal. Em uma das direções o estudante acessa uma barbearia e uma ampla lanchonete; na outra situam-se o refeitório e uma sala de convivência. 


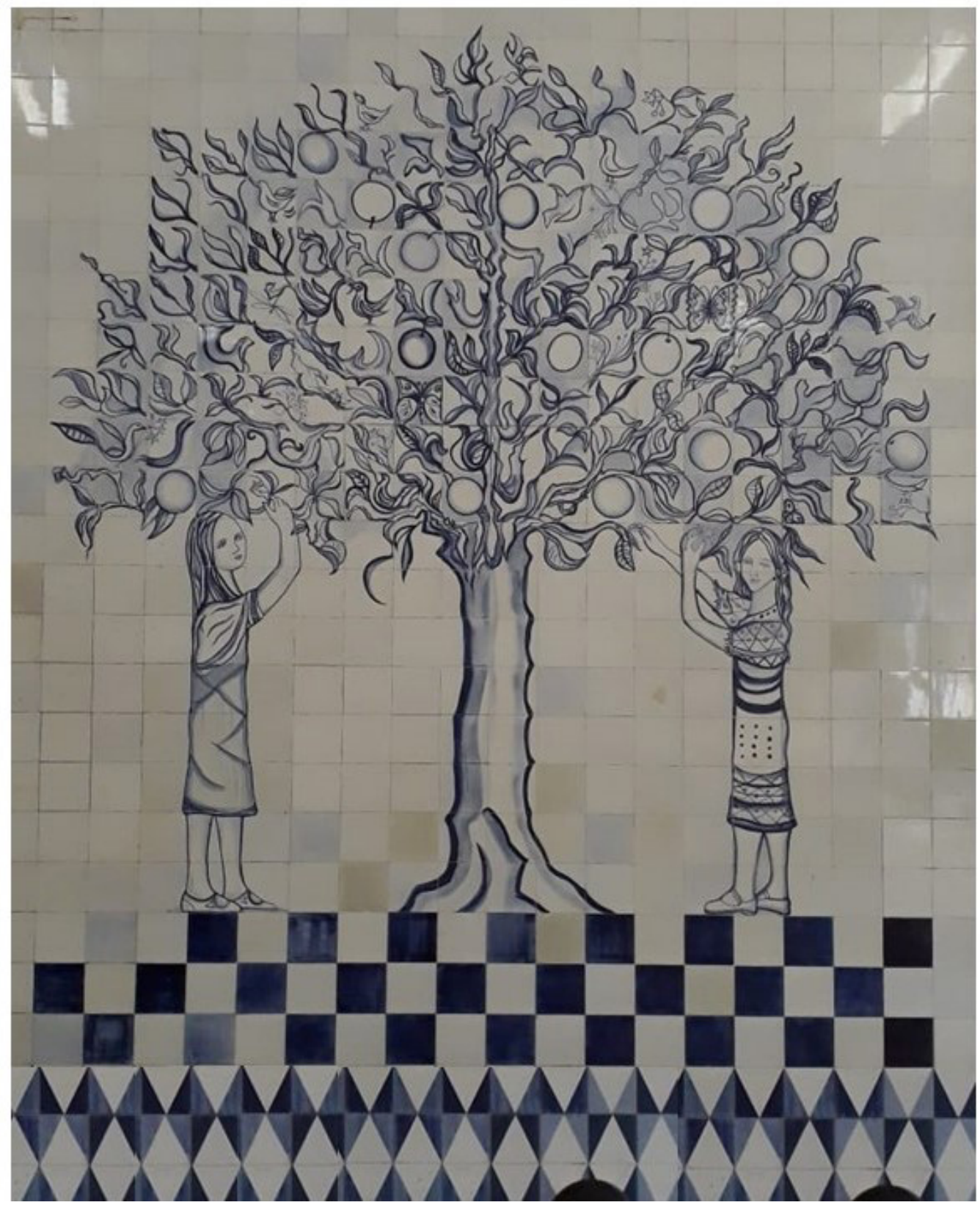

Figura 7: A colheita - quadro central do painel, 2021 Fonte: composição a partir de fotos do autor

Ao ingressar no restaurante, nosso observador se depara com um painel de azulejos decomposto em partes, mas provavelmente seu olhar recaia no quadro central, que constitui o elemento principal da composição. O módulo possui 440 azulejos distribuídos em 22 fiadas de 20 unidades alinhadas horizontalmente, gerando um campo retangular de 303,8 $\times 334,2$ centímetros, sendo o eixo central coincidente com a metade da largura da parede que lhe dá suporte. O quadro não é emoldurado 
por frisos (frações retangulares de azulejos), cercaduras (moldura formada por um azulejo inteiro) ou barras (obtidas por duas fiadas de azulejos) ${ }^{8}$. Nas laterais e na aresta superior, exibe uma laranjeira carregada de frutos e, sob sua copa, duas camponesas simetricamente dispostas à esquerda e à direita do tronco, não por acaso posicionado no eixo central da composição.

A silhueta retilínea dos corpos, muito além de aludir à verticalidade do tronco, estabelece um importante elo entre a barra inferior, composta por um tabuleiro de quadrados, em contraste cromático positivo e negativo, e a copa da laranjeira, conferindo-Ihe maior estabilidade. A massa compacta da copa - preenchida por galhos, folhagens, flores, frutos e insetos perceptíveis a curta distância - cria um semicírculo reconhecível a partir de uma certa distância, contribuindo para aproximar os conteúdos figurados ao tabuleiro do embasamento, que se assemelha a um enxaquetado ${ }^{9}$ de losangos e quadrados, organizados em faixas.

Imediatamente depois de contemplar a cena principal, o estudante é provavelmente atraído pelas personagens inscritas em dois quadros posicionados à esquerda e à direita do módulo central. Ambas são caracterizadas como camponeses que, orgulhosamente, exibem os frutos do seu trabalho. A figura feminina encontra-se à esquerda e suporta sobre a cabeça um cesto carregado de abacaxis. A masculina ocupa um quadro posicionado à direita da laranjeira e exibe um cesto carregado de frutas e vegetais.

Ambos os quadros são compostos por 70 azulejos distribuídos em 14 fiadas de cinco unidades alinhadas horizontalmente, configurando um campo retangular de 75,8 $\mathrm{x}$ 212,6 centímetros não delimitado nas laterais e na porção superior por frisos, cercaduras ou barras. A sensação de verticalidade é reforçada, na figura masculina,

\footnotetext{
${ }^{8}$ Segundo definições propostas por Mário Barata (1955, p. 23) a partir da nomenclatura concebida por João Miguel dos Santos Simões, valendo-se da tradição azulejar lusitana. Para maiores informações, consultar: BARATA, Mário. Azulejos no Brasil: séculos XVII, XVIII e XIX. Rio de Janeiro: Editora Jornal do Commercio, 1955.

${ }^{9}$ Enxaquetados: "composições geométricas compósitas, derivadas do xadrez, usadas em Portugal no século XVI e na primeira metade do século XVII". MECO, José. Glossário. Oceanos, Lisboa, n. 36/37, p. 272, out. 1998 - mar. 1999.
} 
pela estampa da calça listrada; na figura feminina pelo traçado longilíneo do tronco e pela inserção de um xale que pende sobre o seu ombro.
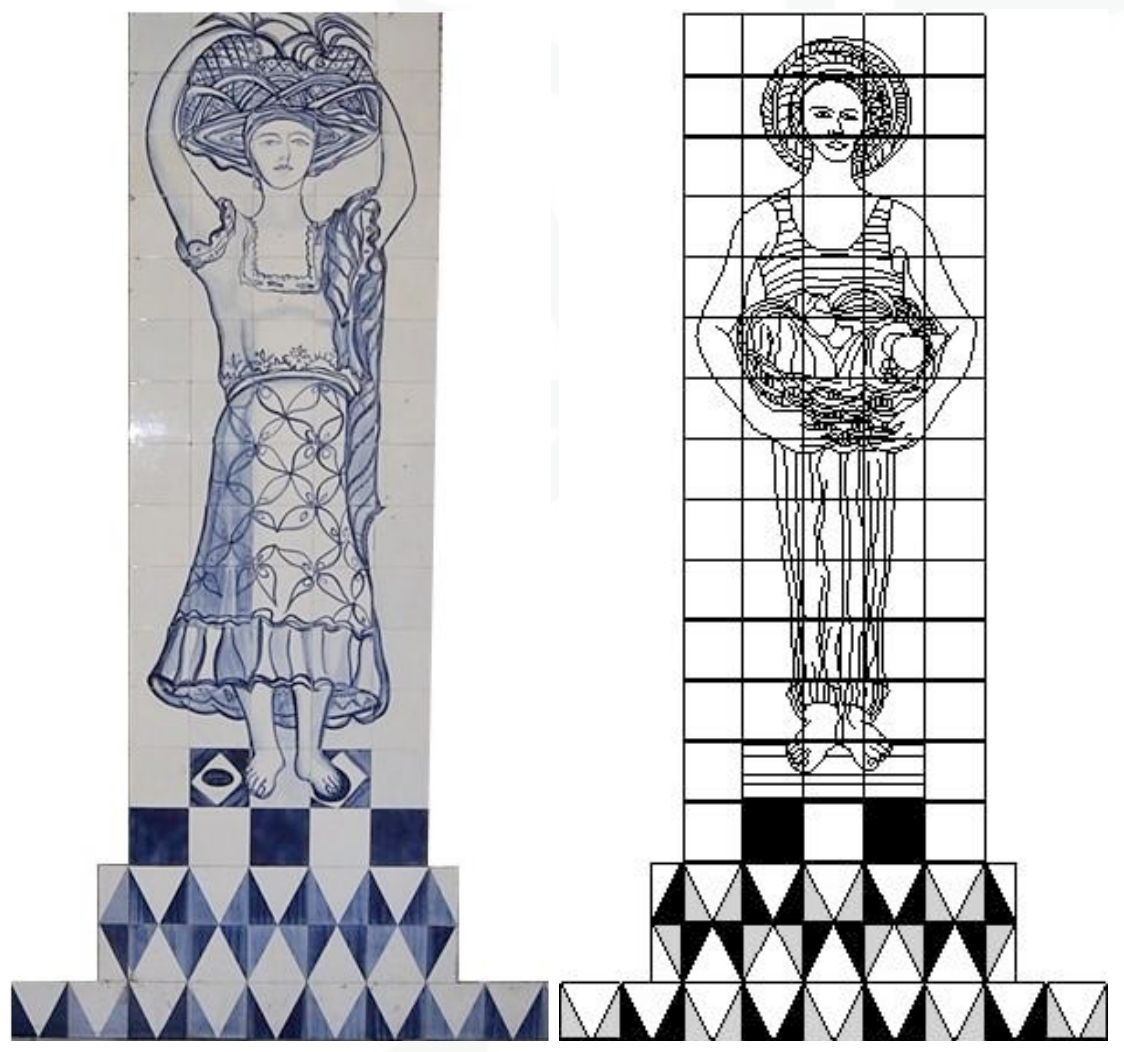

Figuras 8 e 9: Figuras de convite, 2021 Fontes: foto do autor e desenho Renan Santana

O camponês comprime contra o próprio ventre os resultados de uma jornada de trabalho. $\mathrm{O}$ equilíbrio do cesto de abacaxis é garantido pela suspensão arqueada dos braços da agricultora, cuja sinuosidade remete ao formato circular do medalhão a ela sobreposto. $\mathrm{O}$ agricultor parece se assentar sobre uma espécie de pódio, elevando-se do plano do piso. A camponesa se apruma sobre um tabuleiro geométrico de quadrados, círculos e losangos, ora em tons de azul escuro, ora em tons de branco, que conformam uma barra alusiva à bandeira brasileira em dois de seus azulejos.

As dimensões de ambas as personagens, muito próximas da escala natural dos visitantes do refeitório, parecem aludir às antigas figuras de convite, usadas com frequência na azulejaria portuguesa do século XVIII (ARRUDA, 1993). Tal como sugere a própria denominação do termo, a inserção destas figuras humanas pode ser 
interpretada, talvez até pelo nosso interlocutor imaginário, como um atrativo para o ingresso de quem se desloca na circulação avarandada defronte ao refeitório.

Mais acima dos braços arqueados da camponesa se inscreve um quadro assemelhado a um medalhão, composto por dezesseis azulejos que formam um quadrado de 60,6 x 60,6 centímetros. Neste campo é inscrita uma moldura circular decorada com flores e folhas em diversas tonalidades de azul, que contrastam com o fundo branco. Tais elementos, agrupados em quatro grupos, estruturam uma subdivisão da cena em duas partes, contribuindo para destacar o tema principal - no caso dois papagaios assentados em um galho.

Pode-se imaginar a simultânea ou imediata atração do olhar do nosso interlocutor para o quadro sobreposto à figura do camponês, disposto em correlação simétrica em relação ao medalhão anteriormente descrito. Neste módulo de iguais dimensões se inscreve uma moldura circular que exibe seis peixes em movimentação contínua, com fundo pintado em tonalidades aquareladas de azul. O interior do medalhão exalta um único peixe, cuja simbologia remete à ideia de abundância, vida e fertilidade, sobreposto a um grafismo de linhas sinuosas que sugerem escamas, ou ondulações do mar.
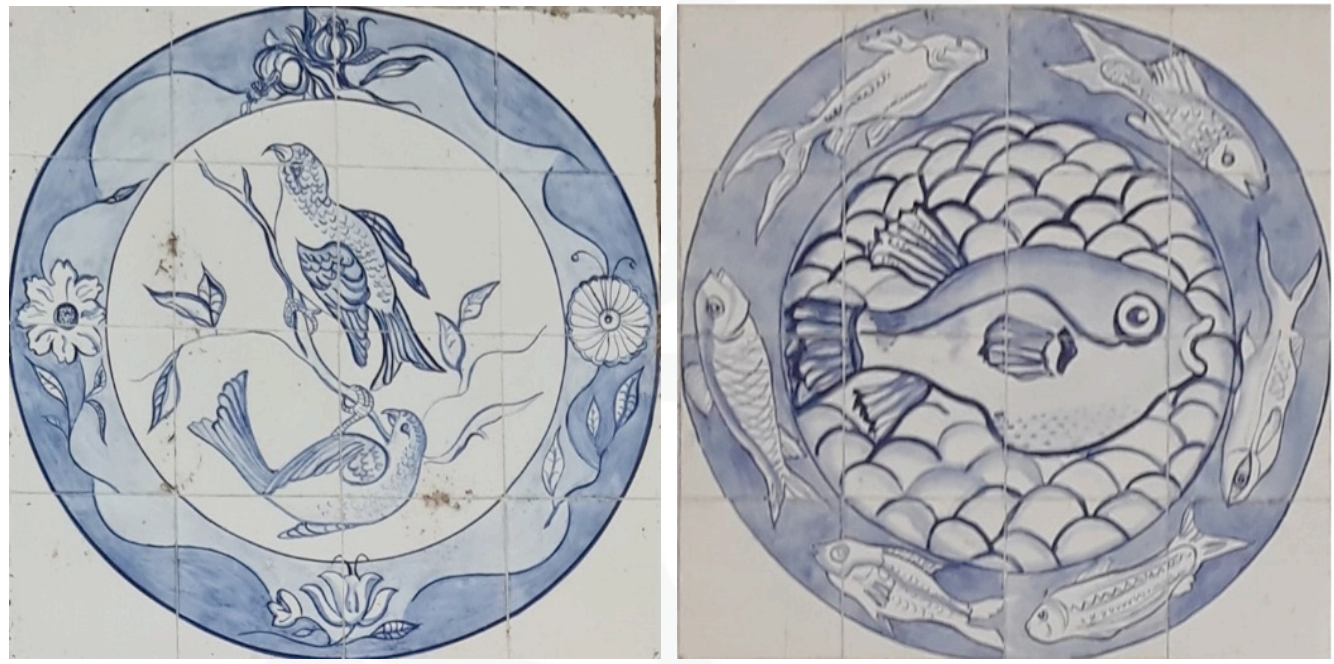

Figuras 10 e 11: Medalhões aves e peixes, 2021 Fonte: fotos do autor 
O universo marítimo transporta nosso observador para um campo assentado diagonalmente entre a figura da camponesa e o quadro central. O campo aqui se configura em 25 azulejos que criam um quadrado de 75,8 centímetros de lado, emoldurado internamente por uma borda ondulada semelhante a um friso. Neste campo são apresentados dois pescadores em uma embarcação rudimentar, similar às jangadas de troncos usadas no nordeste brasileiro. A vela em tecido constitui o principal elemento da cena, que também exibe estrelas, aves, peixes e o perfil sinuoso das ondas do oceano, em arabescos, formando um triângulo isósceles cujo vértice se volta para baixo, em direção oposta ao sentido ascendente da vela.
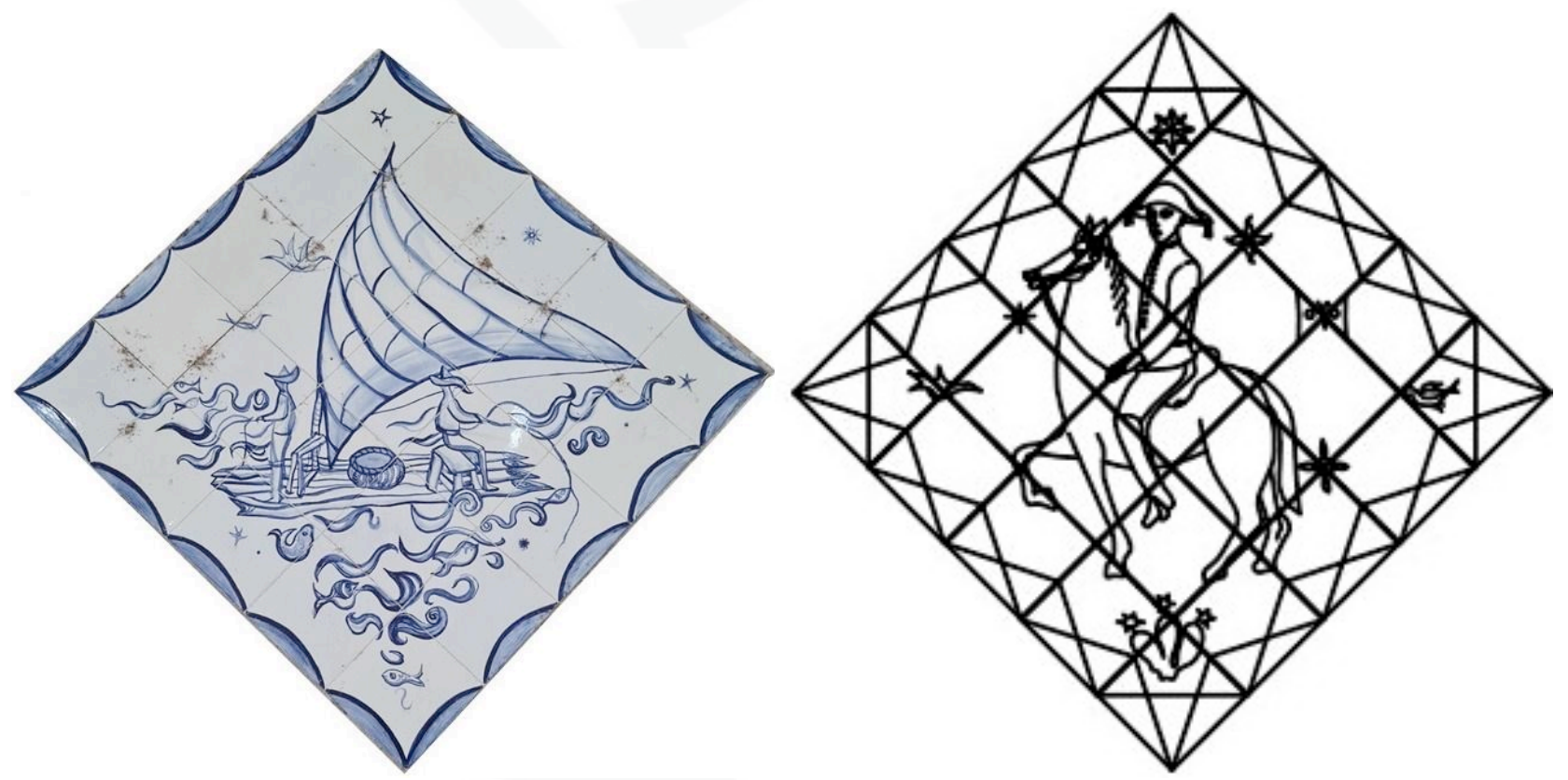

Figuras 12 e 13: Jangadeiros e cangaceiro, 2021 Fontes: foto do autor e desenho Renan Santana

Com igual formato e disposição simétrica equivalente em relação ao quadro central se apresenta mais um módulo assentado em diagonal, que novamente exalta o ambiente rural nordestino. Desta vez a cena é emoldurada internamente por linhas retilíneas entrecruzadas, colocando em destaque a figura de um cavaleiro ladeado por folhagens, pássaros e por uma borboleta, cuja geometrização contrasta com o desenho de uma outra borboleta presente entre as folhagens da laranjeira do 
módulo central. A inserção de um chapéu de couro sobre a cabeça do paladino e dos cactos em flor sob os pés do cavalo convocam a imaginação do nosso visitante para um cenário mais árido, provavelmente inspirado no semiárido brasileiro.

Por fim, o olhar do nosso interlocutor volta-se para apreciar uma rosa dos ventos antropomorfizada, inserida em um quadro não limitado por frisos, cercaduras ou barras. A peça, assentada acima da porta de acesso ao salão, é constituída por dezesseis azulejos que formam um quadrado de 60,6 x 60,6 centímetros. A composição se organiza em duas partes interdependentes. A primeira delas ocupa o centro geométrico do campo e corresponde à sugestão esquematizada de um rosto humano, com sobrancelhas, pálpebras, olhos e boca.

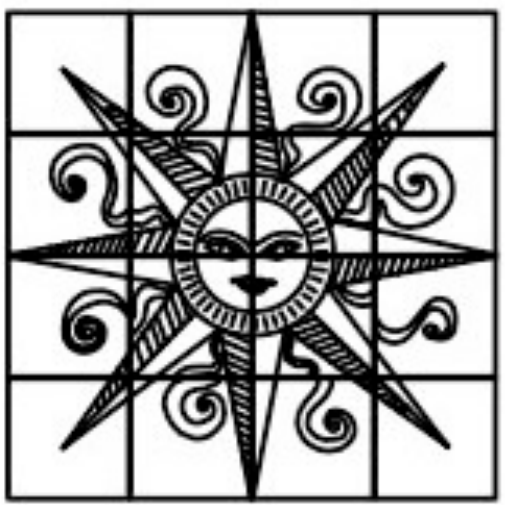

Figura 14: Rosa dos ventos Fonte: desenho Renan Santana, 2021

Em torno deste círculo são inscritos oito triângulos isósceles que indicam os pontos cardeais - Norte (N), Sul (S), Leste (L) e Oeste (W) e os pontos colaterais - Nordeste (NE), Sudeste (SE), Sudoeste (SW), Noroeste (NW). Entre os pontos cardeais e colaterais são acrescentados arabescos que, muito além de aludir a raios solares, dialogam com os grafismos apresentados em outras partes do painel. Tal percepção de unidade é certamente favorecida pela disposição simétrica dos quadros e pelo ritmo das pinceladas que criam flores, folhas, galhos, ondas, tecidos, rendas e estampas. 
O tratamento cromático também contribui para harmonizar o conjunto. Nelas nosso interlocutor identifica algumas tonalidades de branco usadas no fundo da composição, além das diversas intensidades de azul obtidas a partir da diluição do pigmento produzido à base de cobalto, o que simbolicamente remete ao padrão monocromático da azulejaria portuguesa dos séculos XVII e XVIII. (BARATA, 1955).

Ainda que o nosso observador não se aperceba de uma possível correlação entre a obra e as técnicas da azulejaria lusitana e desconheça as origens da autora do painel, seu olhar é convidado a deambular por diferentes paisagens, "reais" ou de "sonhos", conhecidas ou idealizadas. De algum modo, sua jornada estabelece paralelos com uma descrição feita por Cecília Meireles a partir uma visita à exposição de Vieira da Silva na Galeria Askanazy:

Fiz um prodigioso passeio por entre os quadros de Maria Helena. Não havia ninguém, por muito que o lugar convidasse com tantas sugestões. Mas nós sabemos que os homens andam tão transtornados! (...) Não haveria melhor ambiente para os quadros de Maria Helena, que têm todas as virtudes líricas: são íntimos e discretos e falam com vozes familiares que, segundo o ouvinte, podem ser ternos, graves, tremendos, sobrenaturais. (...) Passei por cidade garrida com azuis alegres, janelinhas de festa, grades, sacadas, pórticos, fontes - quem não vê que anda aqui Portugal com sua graça de pormenores? E quem não ouve sua cantiga de sol e mar, e toda a ternura minuciosa de seu povo? Vi os laranjais da Nau Catarineta e as sereias de Camões nadando em si mesmas, nas ondas de seus cabelos, nas ondas de seu corpo, ondas, ondas - nadando no tempo, e assim reduzidas a tão puro movimento que estavam em toda parte sem mudarem de lugar. $E$ na verdade já não estavam: eram. Porque em toda esta pintura nada é de estar, mas tudo é de ser. (MEIRELES, 1944, p. 4)

\section{NAVEGAR, RESISTIR, AFIRMAR-SE}

No final dos anos 1930, Arpad e Maria Helena trilhavam com desenvoltura pela cena parisiense. Os anos de aprendizado na Académie de La Grande Chaumière, somados aos ensinamentos de Charles Dufresne e Fernand Léger, entre outros artistas, confirmaram as apostas depositadas pelos jovens ao deixar Budapeste e Lisboa em 1928. 
Na capital francesa, não encontraram dificuldades para se integrar no meio intelectual, discutindo arte e política com um grupo de comunistas, "Amis du monde", liderado pelo escritor Henri Barbusse. Mas o reconhecimento do talento artístico não foi imediato: "No início da nossa vida de pintor, qualquer pessoa sensata teria sentenciado que caminhávamos para a catástrofe. Raros são os que têm a capacidade de acreditar no êxito". (VIEIRA DA SILVA. In: PHILIPE, 1995, p. 46).

Em 1931, participaram do "Salon des Surindépendants" e pouco depois conheceram a galerista Jeanne Bucher, que editou o livro infantil Ko et Ko, les deux esquimaux, ilustrado por Vieira da Silva em 1933, recusado por um grande editor (PHILIPE, 1994, p. 27-28). O lançamento da publicação foi acompanhado pela exibição dos guaches originais na galeria, onde a artista voltaria a expor em 1937, sinalizando o avanço de uma trajetória promissora.

Em 1939, Arpad expôs individualmente na Galeria Jeanne Bucher, a quem havia confiado os cuidados do ateliê e das obras do casal durante uma temporada em Lisboa, sem data prevista de retorno ${ }^{10}$. Na capital portuguesa, supostamente protegida das ameaças da guerra, Vieira da Silva elaborou uma proposta, por fim recusada, de uma obra artística para a Exposição do Mundo Português, organizada para celebrar as conquistas do mandatário António Salazar. Diante do abismo entre as concepções de arte e mundo, parecia não haver alternativas a não ser marchar para o Brasil que, paradoxalmente, encontrava-se em plena ditadura estadonovista.

A passagem pelo Rio de Janeiro deixou marcas profundas - isolamento, medo, depressão - e poucos registros em primeira pessoa. Entre eles se inscrevem os depoimentos de Vieira da Silva documentados no catálogo da mostra Tempos de Guerra (1986), organizada por Frederico Morais, e as entrevistas concedidas à filósofa Anne Philipe, reunidas na publicação L'Éclat de la Lumière (1978), posteriormente

\footnotetext{
${ }^{10}$ Durante o exílio a interlocução e a admiração recíproca entre Jeanne Bucher e os artistas mantiveramse inalteradas, a ponto da galerista organizar, pouco antes de falecer, em 1946, uma individual de Vieira da Silva em Nova York, inaugurada no ano seguinte, sem sequer ter contato físico com as pinturas, todas realizadas no Rio de Janeiro.
} 
traduzida para a língua portuguesa em O fulgor da luz (1995), lançada pela editora Rolim, com a colaboração da Fundação Arpad Szenes - Vieira da Silva.

Ao conceder importância aos testemunhos, almeja-se privilegiar os impasses subjacentes ao processo criativo, ainda que tais depoimentos sejam assumidamente subjetivos, por vezes imprecisos, mas nem por isso dispensáveis. Com isso, parecenos pertinente reconhecer, em Arpad e Maria Helena, a mesma atitude do contador de histórias descrito por Benjamin em "O narrador", que "retira da experiência o que ele conta: sua própria experiência ou a relatada pelos outros". E incorpora as coisas narradas à experiência dos seus ouvintes" (BENJAMIN, 1987, p. 201).

Em tal viés a narrativa assume uma dimensão utilitária e uma amplitude que transcende a mera informação, "compreensível em si e para si" porém incapaz de suscitar espanto e transmitir saberes. A verdadeira narrativa, defende Benjamin (1987, p. 203-204), possui uma amplitude inexistente na informação: "Ela [a narrativa] conserva suas forças e depois de muito tempo ainda é capaz de se desenvolver", assemelhando-se a "sementes de trigo que durante milhares de anos ficaram fechadas hermeticamente nas câmaras das pirâmides e que conservam até hoje suas forças germinativas".

Vieira da Silva reitera as formulações de Benjamin ao considerar que a capacidade de transmitir conhecimento se esvai a partir do momento em que uma pequena ideia, difundida e explorada à exaustão pelos meios de comunicação de massa, deixa de "ser a semente de uma coisa bela" e "acaba por perder-se". Ao criticar a superficialidade e o excesso de informação, sentencia: "Há demasiado barulho, e sob esse ponto de vista um pouco de crise não seria nada mau." (VIEIRA DA SILVA. In: PHILIPE, 1995, p. 104-105)

Para além das considerações sobre a possibilidade de sobrevivência da experiência (Erfahrung) na modernidade, hipótese defendida com muita cautela em "O narrador", Benjamin (1987, p. 221) questiona "se a relação entre o narrador e sua matéria - a vida humana - não seria uma relação artesanal". E por fim, indaga: "Não seria sua tarefa trabalhar a matéria-prima da experiência - a sua e a dos outros transformando-a num produto sólido, útil e único?" 
A despeito de toda diferença de propósitos, Kilomètre 47 incorpora um saber individual e coletivo, plasmado em um produto sólido, útil e único. Em tal cunho interpretativo, o painel expressa uma visão de mundo (Weltanschauung) em profundo desencanto com os efeitos da mecanização da civilização moderna, sem com isso guardar qualquer traço nostálgico ou retrógrado. Neste raciocínio, estabelece mais uma inaudita conexão com os postulados do jovem Benjamin, que não defende, conforme aponta Michel Löwy (2005, p. 18-19)) “uma volta ao passado, mas um desvio por este, rumo a um futuro utópico". ${ }^{11}$

Murilo Mendes, em texto de apresentação da exposição individual de Vieira da Silva, parece corroborar os ideais revolucionários benjaminianos, ao sentenciar:

A arte de Maria Helena Vieira da Silva representará, futuramente, e de maneira exemplar, o período de reconstrução que se seguiu às experiências do após guerra de 1914-1918. Maria Helena não quis fazer tábua rasa do passado: ao contrário, estudando e meditando a lição da obra dos mestres antigos, recolheu os elementos necessários à conquista do seu estilo, unindo tradição ao espírito de aventura e pesquisa. Estamos diante de um artista eminentemente dialético. (MENDES, 1942, p. 58)

Em diversas situações, Vieira da Silva confidencia ter dificuldades para expressar verbalmente os resultados do seu ofício. Mas o embaraço para encontrar as palavras não constitui impedimento para expressar a dimensão utilitária e os estágios do seu desenvolvimento técnico e científico.

Não é através delas [as palavras] que a experiência se comunica; mas, às vezes, uma palavra abre todas as portas. (...) Sou capaz de explicar como se faz uma água-forte, um buril, uma ponta-seca, uma litografia, um vitral, tudo isso posso eu torná-lo inteligível, com a consciência de não fugir demasiado à verdade. Mas fazer pintura é uma coisa totalmente diferente, porque o ofício e a técnica estão aí intimamente ligados. (...) Tornamo-nos sabedores e esse saber adquirido é difícil de ser dito e explicado (VIEIRA DA SILVA. In: PHILIPE, 1995, p. 68; 82-83).

\footnotetext{
${ }^{11} \mathrm{Na}$ avaliação de Michel Löwy (2005, p. 18), o romantismo revolucionário do jovem Benjamin vislumbra no desvio pelo passado a possibilidade contestar criticamente a "civilização moderna (capitalista) em nome de valores pré-modernos (pré-capitalistas)".
} 
Talvez se possa afirmar que os anos passados no Rio de Janeiro não constituem uma ruptura em termos metodológicos, mas tão apenas um interregno de recolhimento e reflexão. Um tempo de muita angústia e de trabalho árduo, que algum tempo depois seria assim confidenciado ao amigo Carlos Scliar: "Eu me lembro de Santa Teresa, mas às vezes eu fico pensando na sombra daquelas figueiras e, então, sinto o peso delas sobre o meu corpo" (VIEIRA DA SILVA. In: MORAIS, 1986, n.p.).

Seu raciocínio pictórico conservou uma sistemática operativa quase sempre avessa a improvisações em sua gestualidade. Tal procedimento, na pintura a óleo, justifica a adoção de pinceladas curtas, no seu entendimento mais apropriadas para a obtenção dos resultados pretendidos.

A realização do painel de azulejaria não assinala um rompimento radical em termos compositivos, valendo-se da repetição de padrões a partir dos quais se estruturam as folhagens e as estampas dos vestidos das camponesas. Com o mesmo propósito os corpos das personagens e a copa da laranjeira são inscritas em formatos geométricos simples - quadrados, retângulos, triângulos e círculos, evidenciando a unidade modular que estrutura todo o conjunto - no caso, o quadrado.

A definição de um princípio articulador entre as partes, muito além de estruturar o painel, inexoravelmente remete aos princípios compositivos da faiança lusitana. Estão nele reinterpretadas as figuras de convite, os azulejos de repetição, a organização enxaquetada e até mesmo o padrão "estrela e bicha" estilizado na estampa dos vestidos das camponesas. No testemunho da própria artista, os mosaicos, presentes nos motivos tradicionais das casas portuguesas, são de fato uma fonte de inspiração para os seus trabalhos, porquanto concedem vibração e ritmo. Em Kilomètre 47, esses efeitos são acentuados mediante calculada alternância entre claros e escuros, de modo a aproximar a padronagem geométrica das cercaduras e rodapés aos elementos figurados presentes nos diferentes quadros do painel.

Por outro lado, a fatura do painel constitui uma realização mais empírica, na medida em que deflagra a necessidade de adotar procedimentos até então inexplorados pela artista, conforme assinala em depoimento: 
Quando nos deram os pincéis de marta, de pêlo muito comprido, senti um gosto extraordinário em pintar aquelas folhas de laranjeira como se fosse uma aquarela; a matéria da cerâmica é agradável, embebe lindamente. Senti com isso um prazer maravilhoso e aceitei ceder a ele, mas não costumo fazer isso com minha pintura (VIEIRA DA SILVA. In: PHILIPE, 1995, p. 54-55)

Nesta pretensa "falta" de controle da pincelada, a simplificação dos elementos constitui procedimento digno de nota, não apenas por conferir coesão ao conjunto, mas principalmente por imprimir um aspecto de espontaneidade. Em tal estratégia, Vieira da Silva concede primazia ao traço que constrói uma trama na qual os arabescos e bordados dos vestidos das personagens dialogam com o desenho dos insetos, das aves e das folhas da laranjeira.

Para executar o painel, a artista recorreu à técnica do baixo esmalte. Neste procedimento, a tinta é aplicada diretamente sobre a superfície porosa do biscoito recoberto de estanho, fato a exigir extrema exatidão na pincelada. Após a pintura, a peça é queimada em temperatura próxima aos 950 ․ C. Ao final deste processo, o desenho fica debaixo do esmalte, garantindo-Ihe proteção ${ }^{12}$.

A execução do painel contou com a colaboração do cenógrafo Eros Martim Gonçalves, frequentador da Pensão Internacional (LAMEGO, 2007, p. 67). De acordo com Gilberto Camargo (2011), técnico do Estúdio Sarasá, responsável restauração da obra em 2007, os azulejos de $15 \times 15 \mathrm{~cm}$ utilizados na confecção do painel são da marca Klabin Irmãos \& $\mathrm{Cia}^{13}$. A conservadora Eliana Ursine Mello $(2015$, p. 68), por sua vez, acredita que a queima foi acompanhada pelo casal de ceramistas Anna Soares e Adolpho Mandescher na Companhia Cerâmica Brasileira ${ }^{14}$.

\footnotetext{
${ }^{12}$ A fabricação de azulejos, naquela época, era iniciada com a queima da base, também denominada biscoito, resultante da mistura de componentes argilosos, por cerca de 40 horas em temperatura de $1.050^{\circ} \mathrm{C}$. A segunda queima, mais rápida, era feita a cerca de $950^{\circ} \mathrm{C}$ e tinha como propósito a fixação do vidrado, constituído por uma mistura de materiais não argilosos. Na atualidade, a biqueima foi substituída pela monoqueima, utilizada até mesmo em peças decoradas. (OLIVEIRA; HOTZA, 2015).

${ }^{13}$ A empresa Klabin Irmãos \& Cia., outrora líder mundial na produção de revestimentos cerâmicos, situava-se no bairro carioca de Del Castilho, ocupando as instalações da antiga Manufatura Nacional de Porcelanas, adquirida em 1931 por Wolff Klabin. (FEA/USP, 2019).

${ }^{14}$ Para tanto, Mello apoia-se em um dado fornecido por Frederico Morais (1988) - a queima dos painéis Santa Bárbara e Santa Cecília, assinados em 1964 e 1968 pela pintora Djanira, feitos na mesma empresa. Tal informação, associada aos fortes laços de amizade entre Djanira e os casais Mandescher e Szenes/
} 
Ainda que não se possa comprovar, nas fontes consultadas, a participação do casal Mandescher e nem tampouco apontar o local exato da pintura e acabamento das peças, parece-nos relevante entabular paralelos com os procedimentos utilizados para a execução, naquele instante contemporânea, dos painéis do Ministério da Educação e Saúde. Ambos os trabalhos utilizaram esboços em cartão e recorreram à técnica do baixo esmalte para a queima dos azulejos. Além disso, foram empregados padrões de repetição para o preenchimento dos tapetes, como cenário de fundo para a valorização dos elementos em primeiro plano, nos painéis do Ministério, ou como cercaduras que contornam portas e janelas, no Refeitório.

Os métodos de produção, em contrapartida, sinalizam diferenças significativas, sendo a distribuição de tarefas praticada pela Osirarte, fundada pelo artista Paulo Rossi Osir, indicativa de um ritmo mais acelerado de produção, essencial para a execução de diversas encomendas simultâneas à execução das peças destinadas ao Ministério da Educação e Saúde (TARASANTCHI, 1985).

Tal estratégia operativa se evidencia na definição de autoria dos quadros que revestem as diferentes empenas do embasamento da edificação. As superfícies de menor destaque são recobertas com padrões de repetição criados por Paulo Rossi Osir. As de maior evidência, situadas sob o corpo principal da lâmina em altura, voltadas para a avenida Graça Aranha e, na face oposta, para o hall de acesso aos elevadores, exibem motivos não seriados assinados por Cândido Portinari, sobrepostos a tapetes mais elaborados, igualmente inspirados em temas marinhos, pintados em variadas tonalidades de azul cobalto.

Entre as muitas diferenças que caracterizam as realizações, cumpre salientar, para além da mencionada discrepância na organização das tarefas, um inusitado paradoxo: Cândido Portinari, reconhecido como pintor social e construtor de um imaginário mítico, otimista, de exaltação heróica do trabalhador brasileiro, apresenta ao transeunte que deambula pelo embasamento do edifício mensagens dissociadas

Vieira da Silva, corroborada por Morais, constitui o fundamento da hipótese, também respaldada pela provável parceria entre os Mandescher e Djanira em 1959, na execução de um painel implantado na igreja de Santa Rita, em Cataguases. 
das pretensões e valores defendidos pelos promotores do empreendimento, arquitetos inclusive, que vislumbravam no novo Ministério uma radical transformação do país. Vieira da Silva, uma mulher de esquerda, independente e cosmopolita, representante da denominada "Escola de Paris" ${ }^{15}$, bastante identificada com a arte não-figurativa, presta uma homenagem ao trabalho do campo, inscrevendo uma mensagem de confiança no conhecimento, objeto primordial da nova instituição de ensino, ancorada em memórias pessoais e coletivas, postuladas em tradições e tempos diversos.

$\mathrm{Na}$ avaliação da própria artista, o registro das figuras, em sua frontalidade, estabelece correlações com o passado. Mais precisamente, com iluminuras orientais, sendo tal resultado surpreendente por se distanciar dos desígnios inicialmente esboçados, vinculados à prática agrícola predominante da região - o cultivo de laranjas:

No Brasil, durante a guerra, fizemos um grande painel decorativo, em cerâmica. $O$ assunto inspira-se, de certo modo, num motivo oriental: uma laranjeira - o Brasil é a terra das laranjas - e de cada lado um personagem simétrico. Pássaros e borboletas voavam à roda da árvore; era um motivo hierático, raparigas apanhavam os frutos. Só depois de o realizarem é que nos apercebemos de que nos havíamos inspirado num motivo oriental! Não tínhamos copiado (VIEIRA DA SILVA. In: PHILIPE, 1995, p. 54).

Arpad, testemunha de todo o processo, enfatiza o contorno bem delineado das personagens, em avaliação também assinalada por Frederico Morais que concede ao espectador a possibilidade de "juntar as partes isoladas deste jornal azulejado para compor o todo desta arcádia ou utopia rural". Por fim, o crítico vislumbra no painel “(...) um pouco de nostalgia lusitana, expressa na figura feminina ou mesmo nos

${ }^{15}$ O termo "Escola de Paris", cunhado em 1925 pelo crítico André Warnod na revista literária Comédia, não se refere a um movimento ou instituição artística: deve ser entendido como "um agrupamento de tendências contemporâneas, de caráter antiacadêmico e por vezes como sinônimo de arte independente, para o qual contribuíam artistas de diferentes origens, mas que atuavam na França". (SIMIONI, 2021, p. 8.) 
pescadores, um sentimento cavalheiresco do mundo e das relações humanas". (MORAIS, 1986, n.p.)
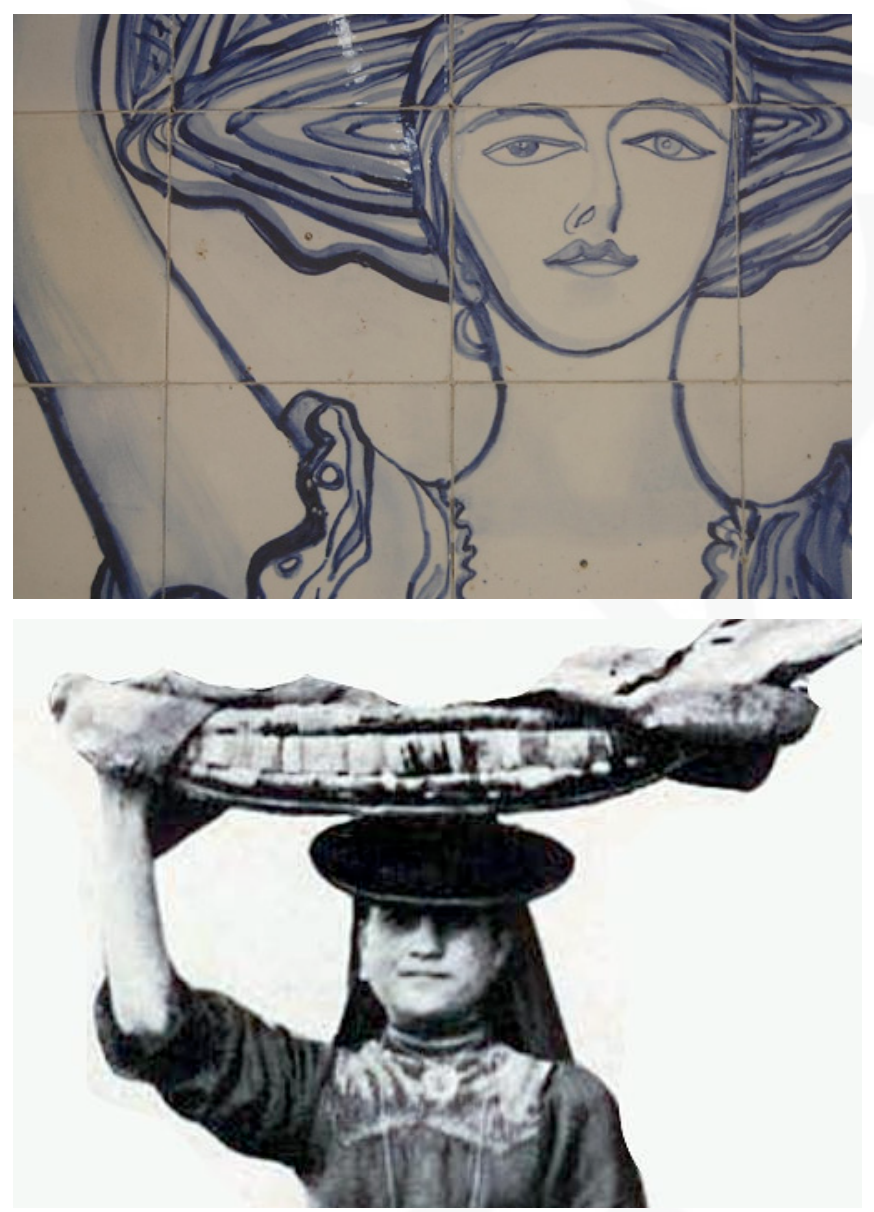

Figuras 15 e 16: Camponesa (detalhe) e varina Fontes: foto do autor, 2021, e portal Folclore de Portugal

Também seria plausível considerar a obra como um tributo à mulher, ainda que naquela altura tal deferência não fosse um expediente frequente. Vistas por esse ângulo, as camponesas de Vieira da Silva se parecem com as varinas lisboetas, que carregam sobre a cabeça gigas repletas de peixes, frutas e hortaliças. Na tradição lusitana, compete à varina conquistar a sua própria independência e decidir as tarefas de cada jornada, conforme a oferta do mercado. Não seria impertinente 
reconhecer, nesta homenagem, inspirada na tradição coletiva e na afirmação da sua própria persona, um reposicionamento da mulher, em todas as esferas da sociedade:

Lembro-me de que quando era criança, se falava das sufragistas. (...). A mulher burguesa achava-se numa situação impossível. Era educada no luxo, mas depois só the restava casar-se. (...) As mulheres pobres viviam esmagadas pela miséria, mas às vezes tinham mais liberdade. No teatro, repare, não há papéis de mulher; a mulher é a amante, a mãe ou a puta. (VIEIRA DA SILVA. In: PHILIPE, 1995, p. 44)

Com o mesmo propósito, pode-se corroborar as formulações da poeta Agustina Bessa-Luís, para quem o painel de Vieira da Silva constitui uma oportunidade de reencontro com a sua própria singularidade, ao sentenciar:

Não se vai ao Brasil para pintar um motivo hierático, mas talvez para resumir o labirinto do próprio espírito: e então podem se criar laranjas e jovens que as guardam, como nos velhos contos medievais. (BESSA-LUÍS, 1982, p. 35)

No mesmo sentido se inscreve uma perspicaz observação da editora e ensaísta Valéria Lamego (2007, p. 58), que vislumbra no ensaio "Dois mil dias no deserto", o encontro de Maria Helena com Vieira da Silva. Um encontro de uma mulher com o seu passado, com as tradições do seu povo. Um doloroso recomeço como artista, alimentado pelo choque da guerra. Um gesto de resistência. E, possivelmente, um voto de confiança na humanidade, singelamente registrado no painel Kilomètre 47.

\section{REFERÊNCIAS}

AGUILAR, Nelson (Org.). Vieira da Silva no Brasil. São Paulo: MAM/SP, 2007.

ARAUJO, Regina Célia Lopes. A universidade no contexto urbano: as representações presentes na relação socioespacial entre a Universidade Federal Rural do Rio de Janeiro e a cidade de Seropédica. 2011. Tese de Doutorado. Instituto de Pesquisa e Planejamento Urbano e Regional, Universidade Federal do Rio de Janeiro, Rio de Janeiro, 2011.

ARRUDA, Luísa d'Orey Capucho. Azulejaria barroca portuguesa: figuras de convite. Lisboa: Edições Inapa, 1993. 
BARATA, Mário. Azulejos no Brasil: séculos XVII, XVIII e XIX. Rio de Janeiro: Editora Jornal do Commercio, 1955.

BENJAMIN, Walter. Magia e técnica, arte e política. Ensaios sobre literatura e história da cultura 3a ed. São Paulo: Brasiliense, 1987.

BENJAMIN, Walter. Passagens de Walter Benjamin. Belo Horizonte: Editora UFMG: São Paulo: Imprensa Oficial do Estado, 2006.

BESSA-LUÍS, Agustina. Longos dias têm cem anos: presença de Vieira da Silva. Lisboa: Imprensa Nacional: Casa da Moeda, 1982.

CESARINY, Mário. Vieira da Silva / Arpad Szenes ou o castelo surrealista: pintura de Vieira e de Szenes nos anos 1930 a 1940 em Lisboa 2a ed. Lisboa: Assírio e Alvim, 2008.

EXPOSIÇÃO de 15 Pintores. Leitura - crítica e informação bibliográfica, Rio de Janeiro, n. 18, p. 8, maio. 1944. Disponível em: http://memoria.bn.br/DocReader/DocReader.aspx?bib=115509\&Pesq=exposi \%c3\%a7\%c3\%a3o\%2015\%20pintores\&pagfis=2928. Acesso em 9 mai. 2021.

LAMEGO, Valéria. Dois mil dias no deserto: Maria Helena Vieira da Silva no Rio de Janeiro, 1940-1947. In: AGUILAR, Nelson (Org.). Vieira da Silva no Brasil. São Paulo: MAM/SP, 2007, p. 53-71.

LIMA CARLOS, Claudio Antonio Santos. Descobrindo o campus da UFRRJ através do seu patrimônio documental. In: Anais do Il Seminário Ibero Americano de Arquitetura e Documentação: desafios e perspectivas. Belo Horizonte: UFMG: IEDS, 2011, v. 1. p. 01-14.

LÖWY, Michael. Walter Benjamin: aviso de incêndio: uma leitura das teses "Sobre o conceito de história". São Paulo: Boitempo, 2005.

MECO, José. Glossário. Oceanos, Lisboa, n. 36/37, p. 270-272, out. 1998 - mar. 1999.

MEIRELES, Cecília. Passeio prodigioso. A Manhã, Rio de Janeiro, p. 4; 6, 13. dez. 1944. Disponível em:

http://memoria.bn.br/DocReader/docreader.aspx?bib=116408\&pasta=ano\%2 0194\&pesq=passeio\%20prodigioso\&pagfis=25165. Acesso em 9 maio. 2021.

MELLO, Eliana Ursine da Cunha. O panorama do patrimônio azulejar contemporâneo brasileiro visto através do seu inventário: do século XX ao século XXI. 2015. Dissertação de mestrado. Escola de Belas Artes, Universidade Federal de Minas Gerais, Belo Horizonte, 2015.

MENDES, Murilo. Exposição de pintura e desenho de Maria Helena Vieira da Silva. Sombra, Rio de Janeiro, n. 10, p. 58, ago./set. 1942. Disponível em: http://memoria.bn.br/DocReader/docreader.aspx?bib=151157\&pasta=ano\%2 0194\&pesq=\%22vieira\%20da\%20silva\%22\%20\%22murilo\%20mendes\%22\&pag fis=1067. Acesso em 9 maio. 2021. 
MONTEIRO, M.C.; MATTOS, R.P. de; BIASE, T. de; FERRAZ, G.M. dos S. Inventário de bens imóveis - ficha sumária da Universidade Federal Rural do Rio de Janeiro Km 47 da Rodovia BR-465, antiga estrada Rio/São Paulo. Proc.: E18/001540/98. Rio de Janeiro: INEPAC, 1998.

MORAIS, Frederico. Cronologia das Artes Plásticas no Rio de Janeiro. Rio de Janeiro: Topbooks, 1995.

MORAIS, Frederico. Tempos de guerra: Hotel Internacional / Pensão Mauá. Rio de Janeiro: Galeria de Arte BANERJ, 1986.

OLIVEIRA, Antonio Pedro Novais de; HOTZA, Dachamir. Tecnologia de fabricação de revestimentos cerâmicos 2aㅡ ed. Florianópolis: Editora da UFSC, 2015.

PAULA, Maria Lúcia Bueno Coelho de. Os mundos da arte de Milton Dacosta. São Paulo, Perspectivas, n. 17-18, p. 267-285, 1994-1995.

PEREIRA, Júlio César Medeiros da Silva. Práticas de saúde, doenças e sociabilidade escrava na Imperial Fazenda de Santa Cruz, da segunda metade do século XIX. Histórica - Revista do Arquivo Público do Estado de São Paulo, São Paulo, n. 35, 2009. Disponível em:

http://www.historica.arquivoestado.sp.gov.br/materias/anteriores/edicao35/ materia01/. Acesso em 8 ago. 2021.

PHILIPE, Anne. O fulgor da luz: conversas com Maria Helena Vieira da Silva e Arpad Szenes. Lisboa: Rolim: Fundação Arpad Szenes - Vieira da Silva, 1995.

SIMIONI, Ana Paula Cavalcanti. Artistas latino-americanos na Paris modernista: a difícil consagração. Anais do Museu Paulista: História e cultura material, São Paulo, Nova Série, v. 29, p. 1-39 e17, 2021. Disponível em: https://www.revistas.usp.br/anaismp/article/view/173891/171819. Acesso em 4 ago. 2021.

SIMÕES, João Miguel dos Santos. Azulejaria portuguesa no Brasil: (1500-1822). Lisboa: Fundação Calouste Gulbenkian, 1965.

TARASANTCHI, Ruth Sprung. Uma iniciativa inovadora. In: PINACOTECA DO ESTADO DE SÃO PAULO. Osirarte: pinturas sobre azulejos de Volpi, Zanini, Hilde Weber e Gerda Brentani. São Paulo, 1985, n.p.

WEELEN, Guy. O azulejo. Lisboa: Imprensa Nacional: Casa da Moeda, 1992.

\section{Fontes eletrônicas e sites}

ARQUIVO NACIONAL. FUNDO: AGÊNCIA NACIONAL - BR RJANRIO EH. Instalações da Escola Nacional de Agronomia na Universidade Rural, Rio de Janeiro, RJ Dossiê. Disponível em: 
https://sian.an.gov.br/sianex/consulta/resultado_pesquisa_new.asp?v_pesqui sa=universidade\%20rural\&v_fundo_colecao=. Acesso em 9 maio. 2021.

BRASIL. CÂMARA DOS DEPUTADOS. Decreto no 8.319, de 20 de outubro de 1910 publicação original. Disponível em: https://www2.camara.leg.br/legin/fed/decret/1910-1919/decreto-8319-20outubro-1910-517122-publicacaooriginal-1-pe.html. Acesso em 21 jul. 2021.

ESTÚDIO SARASÁ. Painel de Vieira da Silva da Universidade Rural do Rio de Janeiro está sendo restaurado pelo Estúdio Sarasá. São Paulo, 7 jan. 2011. Disponível em: https://estudiosarasa.com.br/painel-de-vieira-da-silva-da-universidaderural-do-rio-de-janeiro-esta-sendo-restaurado-pelo-estudio-sarasa/ Acesso em 9 maio. 2021.

FOLCLORE DE PORTUGAL. Varina - a mulher trabalhadora de Lisboa. Disponível em: https://folclore.pt/varina-a-mulher-trabalhadora-de-lisboa/ Acesso em 9 maio. 2021.

FUNDAÇÃO ARPAD SZENES - VIEIRA DA SILVA. Coleção. Vieira da Silva. Disponível em: http://fasvs.pt/coleccao/vieira Acesso em 9 maio. 2021.

UNIVERSIDADE DE SÃO PAULO. FACULDADE DE ECONOMIA E ADMINISTRAÇÃO. Pioneiros \& Empreendedores: a saga do desenvolvimento no Brasil. Disponível em: https://pioneiros.fea.usp.br/lafer-klabin/ Acesso 9 maio. 2021. 